\title{
Phosphorylation Impacts Cu(II) Binding by ATCUN Motifs
}

\author{
Tomasz Frączyk* \\ Cite This: https://doi.org/10.1021/acs.inorgchem.1c00939 \\ Read Online
}

ACCESS |

山ll Metrics \& More

Article Recommendations

Supporting Information

ABSTRACT: ATCUN (amino terminal $\mathrm{Cu}(\mathrm{II})$ and $\mathrm{Ni}(\mathrm{II})$ binding) motifs chelate $\mathrm{Cu}$ (II) ions strongly. However, the impact of the phosphorylation of neighboring residues on such complexation has not been elucidated. The copper(II) dissociation constants of original and phosphorylated peptides from human histatin-1 and human serum albumin were compared using spectroscopic methods. Phosphorylation markedly weakened $\mathrm{Cu}$ (II) binding. Thus, these results indicate that phosphorylation may be a vital mechanism governing metal ion binding.

$\mathrm{M}$ ore than 100 human extracellular proteins and peptides contain an ATCUN motif, ${ }^{1}$ which has an amino acid sequence Xaa-Zaa-His, where Xaa is any amino acid residue with a free N-terminal amine, and Zaa is any amino acid residue except proline. Human histatin-1 and human serum albumin (HSA) contain this motif-Asp-Ser-His and Asp-Ala-His, respectively. $\mathrm{Cu}$ (II) complexes with these molecules are biologically relevant. Such peptides bind $\mathrm{Cu}(\mathrm{II})$ strongly, with subpicomolar to femtomolar dissociation constants. ${ }^{2-6}$

Phosphorylation of serine residues is one of the most frequent post-translational modifications (PTMs). ${ }^{7,8}$ It impacts a range of protein properties, e.g., molecular dynamics, interaction with other molecules or neighboring residues, or the propensity to change the cellular compartment. ${ }^{8}$ However, there is no information about the impact of such phosphorylation on $\mathrm{Cu}$ (II) binding by the ATCUN motif.

Two hexapeptides, N-termini from human histatin-1 (DSHEKR-am) and HSA (DAHKSE-am), were chosen to test the influence of serine phosphorylation on $\mathrm{Cu}$ (II) binding by the ATCUN motif. Spectrophotometric methods revealed the dissociation constants for the original and modified peptides.

First, spectroscopic pH-metric titrations of $\mathrm{Cu}(\mathrm{II}) /$ peptide solutions in a 0.9:1.0 ratio with UV-vis and circular dichroism (CD) spectra registration were performed (Figures 1 and 2). The appearance of $d-d$ bands characteristic of $4 \mathrm{~N}$ square planar complexes was detected by both methods. The $\mathrm{p} K_{\mathrm{a}}$ values for the formation of $4 \mathrm{~N}$ complexes were calculated from the $\mathrm{pH}$ dependence of the absorbance and CD signal (Figure 3), as reported earlier (see also the Supporting Information). ${ }^{9}$ Interestingly, phosphorylation caused an increase in such $\mathrm{p} K_{\mathrm{a}}$ values by $0.3 \mathrm{pH}$ units for both peptides $(4.13 \pm 0.04$ vs $4.37 \pm$ 0.05 for DSHEKR-am and $4.53 \pm 0.04$ vs $4.82 \pm 0.04$ for DAHKSE-am), strongly suggesting that serine phosphorylation decreases the affinity of these peptides for $\mathrm{Cu}$ (II).

According to a recently published approach, ${ }^{2}$ the competition of the hexapeptides and GGH tripeptide for $\mathrm{Cu}$ (II) ions was observed by CD spectroscopy (Figure 4) to examine the influence of serine phosphorylation on $\mathrm{Cu}$ (II) binding by the ATCUN motif. Briefly, CD spectra of $0.67 \mathrm{mM}$ hexapeptide and $0.60 \mathrm{mM} \mathrm{Cu}(\mathrm{II})$ with variable concentrations of $\mathrm{GGH}$ at $\mathrm{pH} 7.4$

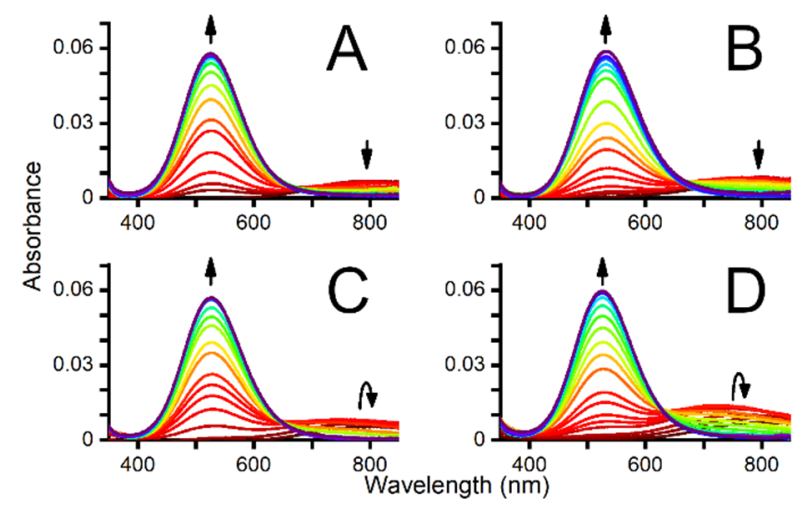

Figure 1. UV-vis spectra of $0.67 \mathrm{mM}$ peptide and $0.60 \mathrm{mM} \mathrm{CuCl}_{2}$ in the $\mathrm{pH}$ range of 3 (red) to 10 (violet). The diminishing (at $800 \mathrm{~nm}$ ) and appearing (at $530 \mathrm{~nm}) d-d$ bands with increasing $\mathrm{pH}$ are shown for A) DSHEKR-am, B) DpSHEKR-am, C) DAHKSE-am, and D) DAHKpSE-am.

(equilibrated for $24 \mathrm{~h}$ ) were recorded. Each spectrum was decomposed to find the component concentrations: $\mathrm{Cu}$ (hexapeptide) and $\mathrm{Cu}(\mathrm{GGH})$ complexes allowing me to compute the relative strength of the hexapeptide with GGH as a reference (Supporting Information).

In detail, the linear dependence is derived from the equation

$$
\frac{K_{\mathrm{f}(\mathrm{Cu}(\text { peptide }))}}{K_{\mathrm{f}(\mathrm{Cu}(G G H))}}=\frac{[\mathrm{Cu}(\text { peptide })]\left([G G H]_{\mathrm{T}}-[\mathrm{Cu}(\mathrm{GGH})]\right)}{[\mathrm{Cu}(\mathrm{GGH})]\left([\text { peptide }]_{\mathrm{T}}-[\mathrm{Cu}(\text { peptide })]\right)}
$$

where $[\mathrm{Cu}$ (peptide) $]$ and $[\mathrm{Cu}(\mathrm{GGH})]$ are measured by decomposition of experimental spectra, and $[\text { peptide }]_{\mathrm{T}}$ and $[\mathrm{GGH}]_{\mathrm{T}}$ are the total concentrations of each ligand. The slope of this dependence is equal to the number saying how many times

Received: March 26, 2021 


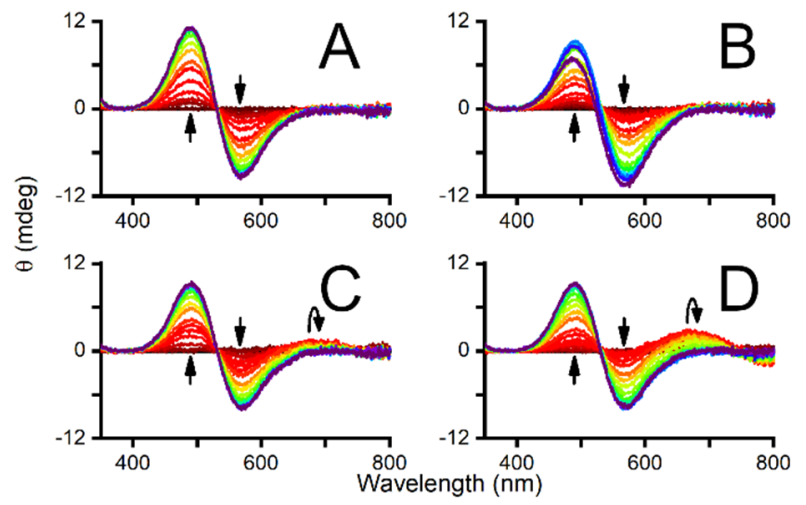

Figure 2. $\mathrm{CD}$ spectra of $0.67 \mathrm{mM}$ peptide and $0.60 \mathrm{mM} \mathrm{CuCl}_{2}$ in the $\mathrm{pH}$ range of 3 (red) to 10 (violet). The appearance of $d-d$ bands at 490 and $570 \mathrm{~nm}$ with increasing $\mathrm{pH}$ is shown for A) DSHEKR-am, B) DpSHEKR-am, C) DAHKSE-am, and D) DAHKpSE-am.
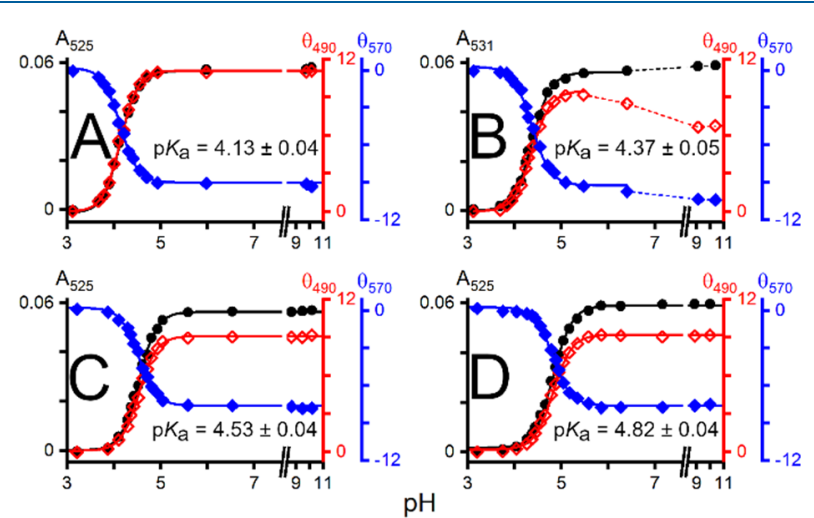

Figure 3. $\mathrm{pH}$ dependence of absorbance and circular dichroism of 0.67 $\mathrm{mM}$ peptide and $0.60 \mathrm{mM} \mathrm{CuCl}_{2}$ for A) DSHEKR-am, B) DpSHEKRam, C) DAHKSE-am, and D) DAHKpSE-am. $\mathrm{p} K_{\mathrm{a}}$ values $( \pm \mathrm{SD})$ for forming $4 \mathrm{~N}$ square planar complexes calculated from the data are also shown for each peptide.

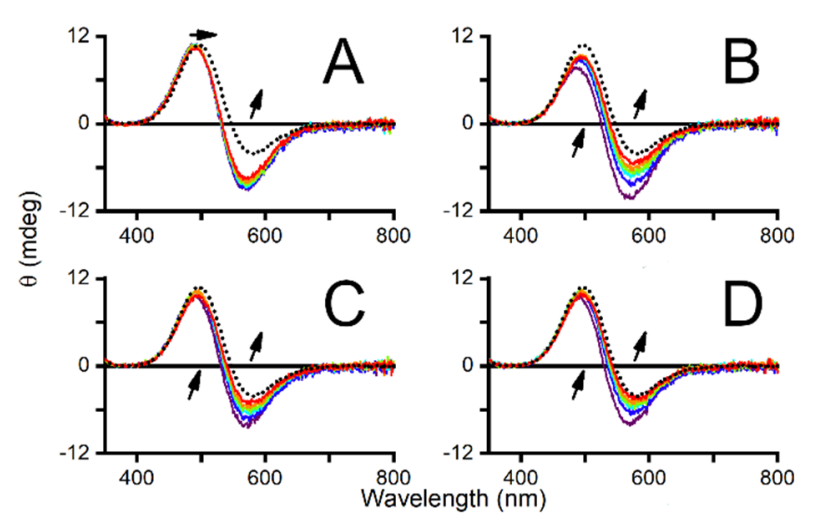

Figure 4. CD spectra of $0.67 \mathrm{mM}$ peptide and $0.60 \mathrm{mM} \mathrm{CuCl}_{2}$ at $\mathrm{pH} 7.4$ (50 mM HEPES) titrated with GGH. The redshifts of the $d-d$ bands from the investigated $\mathrm{Cu}$ (hexapeptide) complex (violet) to $\mathrm{Cu}(\mathrm{GGH})$ (black, dotted) during the titration are shown for A) DSHEKR-am, B) DpSHEKR-am, C) DAHKSE-am, and D) DAHKpSE-am.

the formation constant $\left(K_{\mathrm{f}}\right)$ for $\mathrm{Cu}$ (hexapeptide) is higher than for $\mathrm{Cu}(\mathrm{GGH})$ ( $c f$. Figure 5 and Supporting Information). The dissociation constant of $\mathrm{Cu}(\mathrm{GGH})$ at $\mathrm{pH} 7.4$ was recently determined to be $609.5 \mathrm{fM}\left(\log K_{\mathrm{f}(\mathrm{Cu}(G G H))}=12.215 \pm 0.005\right){ }^{2}$ Thus, one can multiply $K_{\mathrm{f}(\mathrm{Cu}(G G H))}$ by the relevant slope and

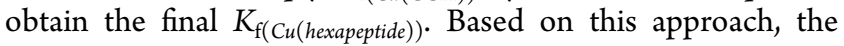
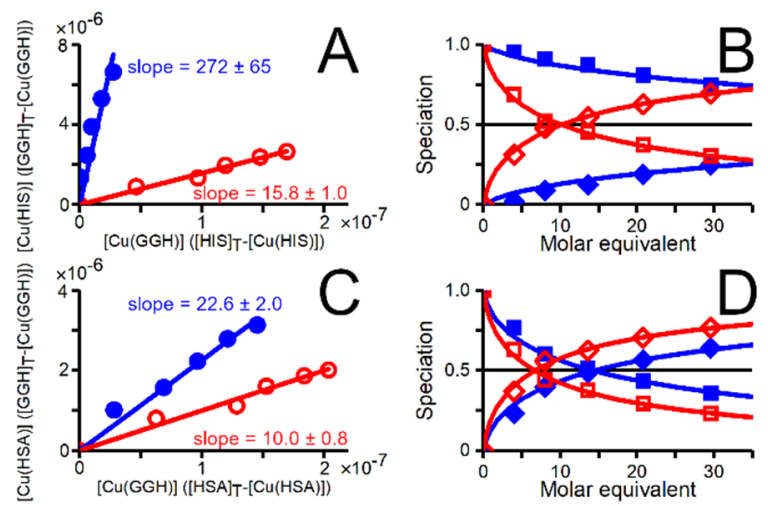

Figure 5. Determination of the relative $\mathrm{Cu}$ (II) binding strength of investigated peptides and GGH, based on the competition experiment shown in Figure 4, calculated for peptides from A) histatin-1 and C) HSA, for nonphosphorylated (blue, dots) and phosphorylated (red, circles) ones. The calculated slopes $( \pm \mathrm{SD})$ reflect the relative $\mathrm{Cu}(\mathrm{II})$ binding affinities. Speciation diagrams were obtained by decomposing the CD spectra from Figure 4 for peptides from B) histatin-1 and D) HSA. Shown are the data for investigated peptides (squares) and GGH (diamonds), either for experiments with nonphosphorylated (blue, full symbols) or phosphorylated versions (red, open symbols).

dissociation constants are $2.2 \mathrm{fM}\left(\log K_{\mathrm{f}}=14.65 \pm 0.12\right)$ and $38.6 \mathrm{fM}\left(\log K_{\mathrm{f}}=13.41 \pm 0.03\right)$ for DSHEKR-am and DpSHEKR-am, respectively. Analogously, $26.9 \mathrm{fM}\left(\log K_{\mathrm{f}}=\right.$ $13.57 \pm 0.05)$ and $60.8 \mathrm{fM}\left(\log K_{\mathrm{f}}=13.22 \pm 0.05\right)$ dissociation constants were found for DAHKSE-am and DAHKpSE-am, respectively. Thus, phosphorylation of nearby serine residues markedly lowers the affinity of the ATCUN motif for $\mathrm{Cu}$ (II) ions. The effect is more pronounced for serine residues in the second position in the sequence compared with the fifth position. This seems reasonable, as serine in the second position is much closer to the coordination sphere.

Interestingly, copper affinities of nonphosphorylated DAHKSE-am and DSHEKR-am differ substantially from each other. Nevertheless, the value for DAHKSE-am is close to that obtained recently for human serum albumin whole protein (log $\left.K_{\mathrm{f}}=13.02 \pm 0.05\right)$. $^{2}$ The affinity for DSHEKR-am, in turn, is equal to the one for DTHFPI-am, the N-terminal motif of hepcidin, claimed to be the strongest $\mathrm{Cu}$ (II) chelator among ATCUN motifs. ${ }^{10}$ Both peptides have an Asp residue in the first position and a Ser or Thr residue in the second. The acidic amino acid residue in the first position and the hydroxylcontaining one in the second position presumably ensure such tight copper binding.

Human histatin-1 and human serum albumin are phosphorylated on serine residues tested in this work. ${ }^{11-13}$ However, about $20 \%$ of human histatin-1 is nonphosphorylated on Ser $2 .{ }^{14,15}$ Although phosphorylation of histatin-1 is beneficial for its binding to hydroxyapatite, ${ }^{16}$ this peptide plays many other roles, e.g., promotes angiogenesis ${ }^{17}$ and exhibits antimicrobial activity. ${ }^{3,18}$ The involvement of phosphorylation in those processes is not known yet. The binding of metal ions by antimicrobial peptides leads to sequestration of this metal from pathogens or is necessary for other antimicrobial modes of action. ${ }^{18}$ Contribution of copper to maintaining microbial oral hygiene is probable as there is an inverse relationship of caries status and $\mathrm{Cu}(\mathrm{II})$ concentration in the saliva of children. ${ }^{19}$ Overall, Ser2 phosphorylation may affect metal-related functions of histatin-1. 
Human serum albumin was found to be phosphorylated on Ser5 by Fam20C kinase. ${ }^{13}$ However, the extent of this phosphorylation is not known. Although only $2 \%$ of ATCUN in HSA is occupied by $\mathrm{Cu}(\mathrm{II})$ ions in blood plasma, ${ }^{20}$ such saturation is not known for other parts of the organism. Most of HSA $(60-70 \%)$ is in the extravascular pool, ${ }^{21}$ e.g., in skin, saliva, and cerebrospinal fluid. ${ }^{22}$ Both saturation with $\mathrm{Cu}$ (II) ions and phosphorylation on Ser5 may differ dramatically from the one in the blood plasma. Such post-translational modification may regulate $\mathrm{Cu}(\mathrm{II})$ binding by HSA locally or transiently.

The influence of amino acid residue type on the stability of the $\mathrm{Cu}$ (II) complex with the ATCUN motif has been thoroughly studied. One of the most evident rules described in the literature is the inverse linear dependence of the affinity to metal ion on the basicity of the N-terminal amine. ${ }^{23,24}$ There is also a hypothesis that the same dependence is valid for amide nitrogens. ${ }^{4}$ Interestingly, the presence of two Asp residues in the ATCUN motif (Asp-Asp-His) is correlated with the highest basicity of the N-terminal amine and, consequently, with the lowest affinity to $\mathrm{Cu}(\mathrm{II}){ }^{24}$ The basicity of amine in the free serine amino acid is also heightened by phosphorylation of its side chain (9.85 vs 9.25). ${ }^{25,26}$ Therefore, the results presented in this work suggest that phosphate moiety, similarly acidic as the Asp side chain, may weaken the binding of $\mathrm{Cu}$ (II) ions by stabilizing the protonated state of the amine and amide nitrogens.

Based on the recent analysis of $\mathrm{N}$-terminal sequences in human proteins, ${ }^{1}$ the selection of human proteins with the ATCUN motif and serine or threonine residue within the first five positions was performed and presented in Table S1. The threonine residue was added to this analysis as its phosphorylation probably shows the same impact on $\mathrm{Cu}$ (II) binding as serine modification. There are 65 human proteins, either secreted or with $\mathrm{N}$-terminus exposed on the extracellular side of the cell membrane, with ATCUN motifs containing at least one Ser or Thr (Table S1). Seven proteins with such sequences are localized in the endoplasmic reticulum or Golgi apparatus. It sums up to 72 proteins localized in relatively oxidizing compartments, thus, with a higher probability to meet divalent copper ions. ${ }^{1}$ Interestingly, more than 100 other proteins are localized in compartments with a more reducing state (Table S1), such as cytoplasm, nucleus, or mitochondrion. ${ }^{1}$ The binding of $\mathrm{Cu}$ (II) by those proteins is questionable (because intracellularly $\mathrm{Cu}(\mathrm{I})$ is more prevalent than $\mathrm{Cu}(\mathrm{II})$ ) but cannot be excluded that may occur transiently or in pathological states. The frequency of Ser or Thr in the sequence position 1, 2, 4, or 5 throughout the whole selection (223 proteins, Table S1) is relatively uniform with a slight prevalence of serine residues (Figure S7).

The results presented in this work indicate that phosphorylation of serine residues markedly weakens the stability of $\mathrm{Cu}$ (II) complexes with the peptides comprising N-terminal sequences of human histatin- 1 and human serum albumin. Thus, phosphorylation is perhaps a mechanism of fine-tuning the metal-related functions of these proteins. It may also be a general mechanism valid for other proteins or peptides with ATCUN motifs.

\section{ASSOCIATED CONTENT}

\section{SI Supporting Information}

The Supporting Information is available free of charge at https://pubs.acs.org/doi/10.1021/acs.inorgchem.1c00939.
Experimental section; details related to decomposition of $\mathrm{CD}$ spectra and determination of $\mathrm{Cu}$ (II) binding affinity; and list of human proteins with ATCUN motif and serine or threonine residue within first five positions (PDF)

\section{AUTHOR INFORMATION}

\section{Corresponding Author}

Tomasz Frączyk - Institute of Biochemistry and Biophysics, Polish Academy of Sciences, 02-106 Warsaw, Poland; ○ orcid.org/0000-0003-2084-3446; Email: tfraczyk@ ibb.waw.pl

Complete contact information is available at:

https://pubs.acs.org/10.1021/acs.inorgchem.1c00939

\section{Author Contributions}

T.F. conceived, designed, performed the experiments and the analysis, and wrote the article.

Notes

The author declares no competing financial interest.

\section{ACKNOWLEDGMENTS}

The equipment used was sponsored in part by the Centre for Preclinical Research and Technology (CePT), a project cosponsored by the European Regional Development Fund and Innovative Economy, The National Cohesion Strategy of Poland.

\section{REFERENCES}

(1) Frączyk, T. $\mathrm{Cu}(\mathrm{II})$-binding $\mathrm{N}$-terminal sequences of human proteins. Chem. Biodiversity 2021, 18, No. e2100043.

(2) Bossak-Ahmad, K.; Frączyk, T.; Bal, W.; Drew, S. C. The subpicomolar $\mathrm{Cu}^{2+}$ dissociation constant of human serum albumin. ChemBioChem 2020, 21, 331-334.

(3) Melino, S.; Santone, C.; Di Nardo, P.; Sarkar, B. Histatins: salivary peptides with copper(II)- and zinc(II)-binding motifs: perspectives for biomedical applications. FEBS J. 2014, 281, 657-672.

(4) Gonzalez, P.; Bossak, K.; Stefaniak, E.; Hureau, C.; Raibaut, L.; Bal, W.; Faller, P. N-terminal Cu-binding motifs (Xxx-Zzz-His, XxxHis) and their derivatives: chemistry, biology and medicinal applications. Chem. - Eur. J. 2018, 24, 8029-8041.

(5) Bossak, K.; Drew, S. C.; Stefaniak, E.; Płonka, D.; Bonna, A.; Bal, $\mathrm{W}$. The $\mathrm{Cu}(\mathrm{II})$ affinity of the $\mathrm{N}$-terminus of human copper transporter CTR1: comparison of human and mouse sequences. J. Inorg. Biochem. 2018, 182, 230-237.

(6) Mital, M.; Wezynfeld, N. E.; Frączyk, T.; Wiloch, M. Z.; Wawrzyniak, U. E.; Bonna, A.; Tumpach, C.; Barnham, K. J.; Haigh, C. L.; Bal, W.; Drew, S. C. A functional role for A $\beta$ in metal homeostasis? $\mathrm{N}$-truncation and high-affinity copper binding. Angew. Chem., Int. Ed. 2015, 54, 10460-10464.

(7) Kumar, A.; Narayanan, V.; Sekhar, A. Characterizing posttranslational modifications and their effects on protein conformation using NMR spectroscopy. Biochemistry 2020, 59, 57-73.

(8) Ardito, F.; Giuliani, M.; Perrone, D.; Troiano, G.; Lo Muzio, L. The crucial role of protein phosphorylation in cell signaling and its use as targeted therapy (Review). Int. J. Mol. Med. 2017, 40, 271-280.

(9) Frączyk, T.; Bonna, A.; Stefaniak, E.; Wezynfeld, N. E.; Bal, W. Peptide bond cleavage by $\mathrm{Ni}$ (II) ions within the nuclear localization signal sequence. Chem. Biodiversity 2020, 17, No. e1900652.

(10) Płonka, D.; Bal, W. The N-terminus of hepcidin is a strong and potentially biologically relevant $\mathrm{Cu}$ (II) chelator. Inorg. Chim. Acta 2018, 472, 76-81.

(11) Oppenheim, F. G.; Yang, Y. C.; Diamond, R. D.; Hyslop, D.; Offner, G. D.; Troxler, R. F. The primary structure and functional characterization of the neutral histidine-rich polypeptide from human parotid secretion. J. Biol. Chem. 1986, 261, 1177-1182. 
(12) Oppenheim, F. G.; Xu, T.; McMillian, F. M.; Levitz, S. M.; Diamond, R. D.; Offner, G. D.; Troxler, R. F. Histatins, a novel family of histidine-rich proteins in human parotid secretion. Isolation, characterization, primary structure, and fungistatic effects on Candida albicans. J. Biol. Chem. 1988, 263, 7472-7477.

(13) Tagliabracci, V. S.; Wiley, S. E.; Guo, X.; Kinch, L. N.; Durrant, E.; Wen, J.; Xiao, J.; Cui, J.; Nguyen, K. B.; Engel, J. L.; Coon, J. J.; Grishin, N.; Pinna, L. A.; Pagliarini, D. J.; Dixon, J. E. A single kinase generates the majority of the secreted phosphoproteome. Cell 2015, 161, 1619-1632.

(14) Lal, K.; Xu, L.; Colburn, J.; Hong, A. L.; Pollock, J. J. The use of capillary electrophoresis to identify cationic proteins in human parotid saliva. Arch. Oral Biol. 1992, 37, 7-13.

(15) Cabras, T.; Fanali, C.; Monteiro, J. A.; Amado, F.; Inzitari, R.; Desiderio, C.; Scarano, E.; Giardina, B.; Castagnola, M.; Messana, I. Tyrosine polysulfation of human salivary histatin 1 . A post-translational modification specific of the submandibular gland. J. Proteome Res. 2007, 6, 2472-2480.

(16) Yin, A.; Margolis, H. C.; Grogan, J.; Yao, Y.; Troxler, R. F.; Oppenheim, F. G. Physical parameters of hydroxyapatite adsorption and effect on candidacidal activity of histatins. Arch. Oral Biol. 2003, 48, $361-368$.

(17) Torres, P.; Díaz, J.; Arce, M.; Silva, P.; Mendoza, P.; Lois, P.; Molina-Berríos, A.; Owen, G. I.; Palma, V.; Torres, V. A. The salivary peptide histatin-1 promotes endothelial cell adhesion, migration, and angiogenesis. FASEB J. 2017, 31, 4946-4958.

(18) Moulahoum, H.; Ghorbani Zamani, F.; Timur, S.; Zihnioglu, F. Metal binding antimicrobial peptides in nanoparticle bio-functionalization: new heights in drug delivery and therapy. Probiotics Antimicrob. Proteins 2020, 12, 48-63.

(19) Duggal, M. S.; Chawla, H. S.; Curzon, M. E. A study of the relationship between trace elements in saliva and dental caries in children. Arch. Oral Biol. 1991, 36, 881-884.

(20) Kirsipuu, T.; Zadorožnaja, A.; Smirnova, J.; Friedemann, M.; Plitz, T.; Tõugu, V.; Palumaa, P. Copper(II)-binding equilibria in human blood. Sci. Rep. 2020, 10, 5686.

(21) Doweiko, J. P.; Nompleggi, D. J. Role of albumin in human physiology and pathophysiology. JPEN, J. Parenter. Enteral Nutr. 1991, 15, 207-211.

(22) Linder, M. C.; Hazegh-Azam, M. Copper biochemistry and molecular biology. Am. J. Clin. Nutr. 1996, 63, 797S-811S.

(23) Młynarz, P.; Gaggelli, N.; Panek, J.; Stasiak, M.; Valensin, G.; Kowalik-Jankowska, T.; Leplawy, M. L.; Latajka, Z.; Kozłowski, H. How the $\alpha$-hydroxymethylserine residue stabilizes oligopeptide complexes with nickel(II) and copper(II) ions. J. Chem. Soc., Dalton Trans. 2000, 1033-1038.

(24) Miyamoto, T.; Fukino, Y.; Kamino, S.; Ueda, M.; Enomoto, S. Enhanced stability of $\mathrm{Cu}^{2+}$-ATCUN complexes under physiologically relevant conditions by insertion of structurally bulky and hydrophobic amino acid residues into the ATCUN motif. Dalton Trans. 2016, 45, 9436-9445.

(25) Zachariou, M.; Traverso, I.; Spiccia, L.; Hearn, M. T. W. Potentiometric investigations into the acid-base and metal ion binding properties of immobilized metal ion affinity chromatographic (IMAC) adsorbents. J. Phys. Chem. 1996, 100, 12680-12690.

(26) Rey, F.; Antelo, J. M.; Arce, F.; Penedo, F. J. Equilibrium constants of metal amino acid complexes. Polyhedron 1990, 9, 665668. 